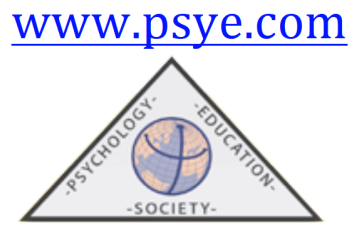

C Psychology, Society, \& Education, 2019. Vol. 11(3), pp. 281-298

ISSN 2171-2085 (print) / ISSN 1989-709X (online)

Doi 10.25115/psye.v10i1.1448

\title{
Critical Status of Research in Ecuadorian Psychology: the Abandonment of Statistics as a Basis of Scientific Production
}

\section{Carlos RAMOS-GALARZA ${ }^{1-2}$, Mónica BOLAÑOS-PASQUEL ${ }^{2}$, Valentina RAMOS ${ }^{3}$, Jaime MOSCOSO-SALAZAR ${ }^{4}$ y Janio JADÁN-GUERRERO ${ }^{2}$}

\author{
${ }^{1}$ Facultad de Psicología, Pontificia Universidad Católica del Ecuador \\ ${ }^{2}$ Laboratorio de Mecatrónica y Sistemas Interactivos, \\ Universidad Tecnológica Indoamérica de Ecuador \\ ${ }^{3}$ Facultad de Administración, Escuela Politécnica Nacional de Ecuador \\ ${ }^{4}$ Facultad de Psicología, Universidad de las Américas de Ecuador
}

(Received on November 20, 2017; Accepted on July 25, 2018)

\begin{abstract}
This article reports a study that analyzed the role of statistics in the scientific production of Ecuadorian psychology based on a mixed methodology study. The sample included 410 participants (students and professionals of different cities of Ecuador). The findings on the quantitative phase included that liking and mastering statistical processes increase the probability of publishing a scientific article. Moreover, when negative belief variables and anxiety related to statistics have a higher score, the mastery of statistical processes and its use for the job of the psychologist decrease. On the qualitative phase, a significance emerged that allowed to better understand quantitative data, and to develop categories on statistics erroneous' believes, procedures, a negative predisposition towards learning statistics and others. The paper concludes by analyzing the scientific reality of Ecuadorian psychology and the need to carry out longitudinal research where it will be possible to restructure subjective constructions on the role of statistics in psychology.
\end{abstract}

Keywords: statistics, scientific production, Ecuadorian psychology, university education.

Estado crítico de la investigación en la psicología ecuatoriana:

el abandono de la estadística como base de la producción científica

RESUMEN: En este artículo se reporta una investigación que analizó el rol de la estadística en la producción científica de la psicología ecuatoriana, para lo cual, se realizó un estudio con metodología mixta. La muestra se conformó por 410 participantes (estudiantes y profesionales de diversas ciudades de Ecuador). En la fase cuantitativa se encontró que, sentir gusto y dominar los procesos de estadística aumentan la probabilidad de publicar un artículo científico, además, cuando las variables creencias negativas sobre estadística y ansiedad por la estadística aumentan en su puntuación, el dominio de los procesos estadísticos y la utilidad de la estadística en el trabajo del psicólogo disminuyen. En la fase cualitativa emergieron significaciones que permitieron comprender de mejor manera los datos 
cuantitativos, en donde se construyeron categorías que tienen que ver con creencias erróneas sobre la estadística, sus procedimientos, una predisposición negativa hacia su aprendizaje y otras. Se concluye el artículo analizando la realidad científica de la psicología ecuatoriana y la necesidad de ejecutar investigaciones longitudinales donde se pueda re-estructurar las construcciones subjetivas sobre la estadística en la psicología.

Palabras Clave: estadística, producción científica, psicología ecuatoriana, formación universitaria.

Correspondending Author: Dr. Carlos Ramos-Galarza, Professor at the Faculty of Psychology of the Pontificia Universidad Católica del Ecuador. Av. 12 de Octubre 1076 y Roca. Quito, Ecuador. Email: caramos@puce.edu.ec

\section{Introduction}

Statistics is a science that analyzes and interprets numerical facts to draw inferences based on their probability (Field, 2009). One of the virtues of applying statistical methods in psychology lies in the great scientific advance it has allowed, which is reflected in its current positioning as a main area of research and its high number of indexed journals found in the most important databases worldwide (Ramos, 2017a).

Scimago Journal Rankings, which is a platform where the impact indicators of Scopus indexed journals are found, has 1063 psychology journals. This is a pretty respectable number compared to other areas of study such as mathematics (1665 journals) or economics and finance (882 journals), which are considered as major traditional areas of scientific research and hold similar number of indexed journals in this database (Ramos-Galarza, 2017).

Despite psychology's worldwide positioning, Ecuadorian psychology has been historically characterized by its lack of application of statistical methods as a mean to prove a hypothesis (Ramos-Galarza, 2017). As evidence of the above mentioned statement, we find that only 113 articles published since 1982 in the area of psychology are found in the Scopus database. From this articles, only 34 report a specific research in psychology or were developed by investigators that belong to an institution of Ecuador (see Table 1), while the other 79 studies belong to other areas, being neurology the most common, followed by business administration, biology, social communication and tourism and in some cases the papers were not written by authors belonging to any Ecuadorian institution. 
Table 1. Articles performed in Ecuador in the area of Psychology 1984-2017

\begin{tabular}{l} 
Title of the Article \\
\hline 1. A cross-cultural study: a comparison of \\
German, Spanish and Ecuadorian \\
Alcoholics using the Munich Alcoholism \\
Test (MALT) \\
2. An initial investigation of validation of \\
the matrix analogies test-expanded form \\
in Ecuador \\
3. Sexual violence against people with \\
developmental disabilities in institutions
\end{tabular}

4. Low socioeconomic status predicts abnormal eating attitudes in Latin

American female adolescents

5. Interacción Familia-Escuela. Análisis de contenido sobre el discurso de docentes y familias.

6. Evaluación de la astenia en pacientes oncológicos

Avanzados y una propuesta de protocolo de intervención Psicológica

7. Is prosodic development correlated with grammatical and lexical development? Evidence from emerging intonation in Catalan and Spanish

8. Continuing bonds reported by bereaved individuals in Ecuador

9. Validity of the trait emotional intelligence questionnaire in sports and its links with performance satisfaction

10. Epidemiological survey of suicide ideation and acts and other deliberate selfharm among offenders in the community under supervision of the Probation Service in England and Wales

11. An investigation into prospective memory in children with developmental dislexia

12. Interpersonal Trust in Ecuador, the United States, and Zimbabwe

13. Happiness and health and food-related variables: Evidence for different age groups in Chile

14. Teachers' implicit theories of learning to read: A cross-cultural study in IberoAmerican countries

Authors
Gorenc, Bruner,
Nadelsticher y
Pacurucu (1984).

Proctor, Kranzler,
Rosenbloom, Martínez
y Guevara (2000)

Zemp, A. (2002).

Canadas (2008)

Álvarez, Aguirre y

Vaca (2010).

Haro et al., (2011)

Frequencies \&

percentages.

Prieto, Estrella y Del

Mar (2011)

Foster, Roth,

Contreras, Gilmer y

Gordon (2012)

Laborde, Dosseville, Guillén y Chávez

(2014)

Pluck y Brooker

Khan (2014)

Mealy, Stephan, Mhaka-Mutepfa, y Alvarado-Sánchez (2015)

Lobos, Mora, Lapo, Caligari, \&Schnettler (2015)

Jiménez et al. (2015)

$\begin{array}{ll}\begin{array}{l}\text { Statistics Technique } \\ \text { used }\end{array} & \begin{array}{l}\text { Place } \\ \text { Rese }\end{array} \\ \text { Psychometric to } & \text { Eculidate instruments. } \\ \text { Comparison of } & \text { Españ } \\ \text { averages and } & \text { Alem } \\ \text { correlations. } & \end{array}$

Alpha of Cronbach, $t \quad$ Ecuador
test, correlation and
factorial analysis.

Measures of centra tendency and dispersion.

Correlation and lineal Ecuador regression.

Frequencies \& percentages.

Measures of central tendency and dispersion.

Measures of central tendency and dispersion.

Factorial confirmation France Analysis \& Path

Analysis.

Measures of central tendency and dispersion.

Average Comparison with ANOVA.

MANOVA, Alpha of Cronbach, correlation, Path Analysis.

Ordinal Logistic Regression and rate of verisimilitude chi square.

Explanatory Factorial Analysis
Ecuador

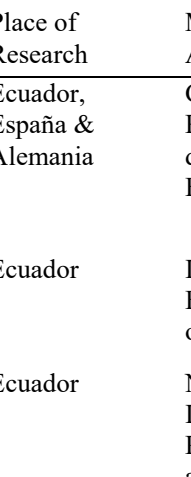

Main Affiliation Second

Centro de

Rehabilitación Nacional de de Alcohólicos, Ciencias Ecuador Penales, México.

Instituto University of Endocrinológic Florida o, Ecuador

None

Institution.

Personal

address in

Otavalo,

Ecuador

Universidad

Católica de

Ecuador

Universidad

Técnica

Particular de

Loja de

Ecuador

Hospital

Virgen de la

Luz, Cuenca-

Ecuador

\section{Spain \\ Universidad}

Católica de

Ecuador mpeuFabra, España.

\section{Ecuador}

Servidores de

Vanderbilt

la fe y la University,

tecnología, Nashville,

Ecuador. United States

Escuela

Politécnica del

Ejercito

England and

Universidad

San Francisco

de Quito,

Ecuador

London,

United

Kingdom

Indian Institute of Technology

Bombay, India

Universidad

de Cuenca,

Ecuador

Ecuador,

USA \&

Zimbabwe

Universidad de

Guayaquil,

Ecuador

University of

Zimbabwe,

Harare,

Zimbabwe

Chile

Universidad

Católica de

Universidad

Guayaquil,

de Talca,

Ecuador

Spain, México,

Universidad

Universidad

Guatemala

Colombia \&

Casa Grande,

Ecuador

de la Laguna,

Spain 


\begin{tabular}{|c|c|c|c|c|c|}
\hline Title of the Article & Authors & $\begin{array}{l}\text { Statistics Technique } \\
\text { used }\end{array}$ & $\begin{array}{l}\text { Place of } \\
\text { Research }\end{array}$ & $\begin{array}{l}\text { Main } \\
\text { Affiliation }\end{array}$ & $\begin{array}{l}\text { Second } \\
\text { Affiliation }\end{array}$ \\
\hline $\begin{array}{l}\text { 15. Personality disorder in a probation } \\
\text { cohort: Demographic, substance misuse } \\
\text { and forensic characteristics }\end{array}$ & $\begin{array}{l}\text { Pluck, Brooker, } \\
\text { Blizard, \& Moran } \\
(2015)\end{array}$ & $\begin{array}{l}\text { Measures of central } \\
\text { tendency and } \\
\text { dispersion. } \\
\text { Regression, logistics } \\
\text { and Odds ratios. }\end{array}$ & $\begin{array}{l}\text { United } \\
\text { Kingdom }\end{array}$ & $\begin{array}{l}\text { Universidad } \\
\text { San Francisco } \\
\text { de Quito, } \\
\text { Ecuador }\end{array}$ & $\begin{array}{l}\text { University of } \\
\text { London, } \\
\text { United } \\
\text { Kingdom }\end{array}$ \\
\hline $\begin{array}{l}\text { 16. Prevalence of Autism Spectrum } \\
\text { Disorders in Ecuador: A Pilot Study in } \\
\text { Quito }\end{array}$ & $\begin{array}{l}\text { Dekkers,Groot, Díaz, } \\
\text { Andrade, \&Delfos } \\
(2015)\end{array}$ & $\begin{array}{l}\text { Measures of central } \\
\text { tendency and } \\
\text { dispersion. Chi square } \\
\text { and Kruskal-Wallis } \\
\text { test. }\end{array}$ & Ecuador & $\begin{array}{l}\text { Centro Meta, } \\
\text { Ecuador }\end{array}$ & $\begin{array}{l}\text { University of } \\
\text { Amsterdam, } \\
\text { Netherlands }\end{array}$ \\
\hline $\begin{array}{l}\text { 17. Un análisis documental de la } \\
\text { investigación en dislexia en la edad adulta }\end{array}$ & $\begin{array}{l}\text { Soriano-Ferrer \& } \\
\text { Piedra-Martínez } \\
(2016)\end{array}$ & $\begin{array}{l}\text { Frequencies \& } \\
\text { percentages. }\end{array}$ & Ecuador & $\begin{array}{l}\text { Universidad del } \\
\text { Azuay, } \\
\text { Ecuador }\end{array}$ & $\begin{array}{l}\text { Universidad } \\
\text { de Valencia }\end{array}$ \\
\hline $\begin{array}{l}\text { 18. Investigación-acción-participativa y } \\
\text { renovación urbana en el barrio } \\
\text { patrimonial La Ronda de Quito }\end{array}$ & $\begin{array}{l}\text { Rodríguez-Mancilla \& } \\
\text { Boada (2016) }\end{array}$ & $\begin{array}{l}\text { Frequencies \& } \\
\text { percentages. }\end{array}$ & Ecuador & $\begin{array}{l}\text { Universidad } \\
\text { Politécnica } \\
\text { Salesiana, } \\
\text { Ecuador }\end{array}$ & None \\
\hline $\begin{array}{l}\text { 19. Cortisol response to acute stress in } \\
\text { asthma: Moderation by depressive mood }\end{array}$ & $\begin{array}{l}\text { Trueba, Simon, } \\
\text { Auchus, \& Ritz (2016) }\end{array}$ & $\begin{array}{l}\text { Mix Anova } \\
\text { Moderation Analysis. }\end{array}$ & USA & $\begin{array}{l}\text { Universidad } \\
\text { San Francisco } \\
\text { de Quito, } \\
\text { Ecuador }\end{array}$ & $\begin{array}{l}\text { Southern } \\
\text { Methodist } \\
\text { University, } \\
\text { Dallas, TX, } \\
\text { United States }\end{array}$ \\
\hline $\begin{array}{l}\text { 20. Development of SFON in Ecuadorian } \\
\text { Kindergartners }\end{array}$ & $\begin{array}{l}\text { Bojorque, Torbeyns, } \\
\text { Hannula-Sormunen, \& } \\
\text { Van Nijlen (2016) }\end{array}$ & $\begin{array}{l}\text { Kappa of Cohen } \\
\text { coefficient Correlation }\end{array}$ & Ecuador & $\begin{array}{l}\text { Center for } \\
\text { Instructional } \\
\text { Psychology and } \\
\text { Technology. } \\
\text { Bélgica. }\end{array}$ & $\begin{array}{l}\text { Universidad } \\
\text { de Cuenca, } \\
\text { Ecuador. }\end{array}$ \\
\hline $\begin{array}{l}\text { 21. The relationship between hunger and } \\
\text { mental health outcomes among school- } \\
\text { going Ecuadorian adolescents }\end{array}$ & $\begin{array}{l}\text { Romo, Abril-Ulloa, \& } \\
\text { Kelvin (2016) }\end{array}$ & $\begin{array}{l}\text { Chi square. } \\
\text { Multivariable Logistic } \\
\text { Regression. }\end{array}$ & Ecuador & $\begin{array}{l}\text { University of } \\
\text { New York, } \\
\text { USA. }\end{array}$ & $\begin{array}{l}\text { Universidad } \\
\text { de Cuenca, } \\
\text { Ecuador. }\end{array}$ \\
\hline $\begin{array}{l}\text { 22. Bifactor modeling of the behavior } \\
\text { rating inventory of executive function } \\
\text { (BRIEF) in a Chilean sample }\end{array}$ & $\begin{array}{l}\text { Pérez-Salas, Ramos, } \\
\text { Oliva, \& Ortega } \\
(2016)\end{array}$ & $\begin{array}{l}\text { Bi-factor modeled } \\
\text { analysis of second } \\
\text { order. Confirmation } \\
\text { Factorial Analysis. } \\
\text { Correlation \& Alpha } \\
\text { of Cronbach. }\end{array}$ & Chile & $\begin{array}{l}\text { Universidad } \\
\text { Tecnológica } \\
\text { Indoamérica, } \\
\text { Ecuador. }\end{array}$ & $\begin{array}{l}\text { Universidad } \\
\text { de } \\
\text { Concepción, } \\
\text { Chile }\end{array}$ \\
\hline $\begin{array}{l}\text { 23. Exploring learning potential in } \\
\text { schizophrenic inpatients in different } \\
\text { psychopathological conditions }\end{array}$ & $\begin{array}{l}\text { González, Beltrán, \& } \\
\text { Martínez (2016) }\end{array}$ & $\begin{array}{l}\text { Frequencies \& } \\
\text { percentages. }\end{array}$ & Spain & $\begin{array}{l}\text { Universidad } \\
\text { Nacional de } \\
\text { Educación, } \\
\text { Ecuador. }\end{array}$ & $\begin{array}{l}\text { Servicio de } \\
\text { Salud de } \\
\text { Asturias, } \\
\text { España }\end{array}$ \\
\hline $\begin{array}{l}\text { 24. Content and Valence of Sexual } \\
\text { Cognitions and Their Relationship } \\
\text { With Sexual Functioning in Spanish Men } \\
\text { and Women }\end{array}$ & $\begin{array}{l}\text { Moyano, Byers, \& } \\
\text { Sierra(2016) }\end{array}$ & $\begin{array}{l}\text { Alpha of Cronbach, } \\
\text { Anova, T-Student, \& } \\
\text { correlation. }\end{array}$ & Spain & $\begin{array}{l}\text { Universidad de } \\
\text { Granada, } \\
\text { España. }\end{array}$ & $\begin{array}{l}\text { Universidad } \\
\text { Espíritu } \\
\text { Santo, } \\
\text { Ecuador. }\end{array}$ \\
\hline $\begin{array}{l}\text { 25. Fluctuating emotions: relating } \\
\text { emotional variability and job satisfaction. }\end{array}$ & $\begin{array}{l}\text { Xu, Martínez, } \\
\text { VanHoof, Eljuri, \& } \\
\text { Arciniegas(2016) }\end{array}$ & $\begin{array}{l}\text { Mediation \& } \\
\text { Moderation analysis. }\end{array}$ & Ecuador & $\begin{array}{l}\text { Universidad de } \\
\text { Cuenca, } \\
\text { Ecuador. } \\
\text { Universidad de } \\
\text { Azuay, } \\
\text { Ecuador. }\end{array}$ & $\begin{array}{l}\text { Hospital de } \\
\text { Pensilvania, } \\
\text { USA. }\end{array}$ \\
\hline $\begin{array}{l}\text { 26. Motivational profiles in physical } \\
\text { education students from three countries } \\
\text { and their relationship with physical } \\
\text { activity }\end{array}$ & $\begin{array}{l}\text { Franco, Coterón, } \\
\text { Martínez, \& } \\
\text { Brito(2017) }\end{array}$ & $\begin{array}{l}\text { Confirmation Factorial } \\
\text { Analysis, chi square, } \\
\text { cluster analysis \& } \\
\text { MANOVA. }\end{array}$ & $\begin{array}{l}\text { Colombia \& } \\
\text { Ecuador }\end{array}$ & $\begin{array}{l}\text { Centro } \\
\text { Universitario } \\
\text { Cardenal } \\
\text { Cisneros, } \\
\text { Madrid, España }\end{array}$ & $\begin{array}{l}\text { Universidad } \\
\text { de Cuenca, } \\
\text { Ecuador }\end{array}$ \\
\hline $\begin{array}{l}\text { 27. Spanish adaption of passion scale in } \\
\text { sport context }\end{array}$ & $\begin{array}{l}\text { Pedrosa, García- } \\
\text { Cueto, Torrado, \& } \\
\text { Arce }(2017)\end{array}$ & $\begin{array}{l}\text { Confirmation Factorial } \\
\text { Analysis \& } \\
\text { MANOVA. }\end{array}$ & Spain & $\begin{array}{l}\text { Universidad } \\
\text { Católica de } \\
\text { Ecuador }\end{array}$ & $\begin{array}{l}\text { Universidad } \\
\text { de Oviedo, } \\
\text { España }\end{array}$ \\
\hline
\end{tabular}




\begin{tabular}{|c|c|c|c|c|c|}
\hline Title of the Article & Authors & $\begin{array}{l}\text { Statistics Technique } \\
\text { used }\end{array}$ & $\begin{array}{l}\text { Place of } \\
\text { Research }\end{array}$ & $\begin{array}{l}\text { Main } \\
\text { Affiliation }\end{array}$ & $\begin{array}{l}\text { Second } \\
\text { Affiliation }\end{array}$ \\
\hline $\begin{array}{l}\text { 28. Inhibitory control and monitoring in } \\
\text { child population with ADHD }\end{array}$ & $\begin{array}{l}\text { Ramos-Galarza \& } \\
\text { Pérez-Salas (2017) }\end{array}$ & $\begin{array}{l}\text { Measures of Central } \\
\text { tendency and } \\
\text { dispersion, t-Student } \\
\text { \& correlation. }\end{array}$ & Ecuador & $\begin{array}{l}\text { Universidad } \\
\text { Internacional } \\
\text { SEK Ecuador }\end{array}$ & $\begin{array}{l}\text { Universidad } \\
\text { de } \\
\text { Concepción, } \\
\text { Chile }\end{array}$ \\
\hline $\begin{array}{l}\text { 29. Validation for the Ecuadorian context } \\
\text { of the APO inventory created in Portugal }\end{array}$ & $\begin{array}{l}\text { Ramos, Mejía, Mejía, } \\
\text { Unada, \&Jordão } \\
\text { (2017) }\end{array}$ & $\begin{array}{l}\text { Explanatory Factorial } \\
\text { Analysis \& Alpha of } \\
\text { Cronbach. }\end{array}$ & Ecuador & $\begin{array}{l}\text { Escuela } \\
\text { Politécnica } \\
\text { Nacional }\end{array}$ & $\begin{array}{l}\text { Universidade } \\
\text { Do Porto, } \\
\text { Portugal }\end{array}$ \\
\hline $\begin{array}{l}\text { 30. Sexual Desire Inventory: Two or } \\
\text { Three Dimensions? }\end{array}$ & $\begin{array}{l}\text { Moyano, P., \& Sierra, } \\
\text { Sexual } \\
\text { DesireInventory: } \\
\text { TwoorThreeDimensio } \\
\text { ns?, (2017) }\end{array}$ & $\begin{array}{l}\text { Explanatory \& } \\
\text { Confirming Factorial } \\
\text { Analysis, Path } \\
\text { analysis \& t- Student. }\end{array}$ & Spain & $\begin{array}{l}\text { Universidad de } \\
\text { Granada, } \\
\text { España }\end{array}$ & $\begin{array}{l}\text { Universidad } \\
\text { Espíritu } \\
\text { Santo, } \\
\text { Ecuador }\end{array}$ \\
\hline $\begin{array}{l}\text { 31. Automaticity of access to arithmetic } \\
\text { knowledge in Alzheimer's disease and } \\
\text { mild cognitive impairment }\end{array}$ & $\begin{array}{l}\text { Jurado \&Rosselli } \\
\text { (2017) }\end{array}$ & $\begin{array}{l}\text { Comparison of } \\
\text { averages thru mix } \\
\text { ANOVA. }\end{array}$ & Florida, USA & $\begin{array}{l}\text { Hospital } \\
\text { Kennedy, } \\
\text { Ecuador }\end{array}$ & $\begin{array}{l}\text { Florida } \\
\text { AtlanticUniv } \\
\text { ersity }\end{array}$ \\
\hline $\begin{array}{l}\text { 32. Adaptation and validation of the } \\
\text { sexual self-consciousness scale in } \\
\text { Ecuadorian women }\end{array}$ & $\begin{array}{l}\text { Moyano, Dib-Fayad, } \\
\text { \&Vélez- } \\
\text { Schemankewitz } \\
(2017)\end{array}$ & $\begin{array}{l}\text { Confirmation Factorial } \\
\text { Analysis, correlation, } \\
\text { Anova \& t de Student. }\end{array}$ & Ecuador & $\begin{array}{l}\text { Universidad de } \\
\text { Zaragoza, } \\
\text { España. }\end{array}$ & $\begin{array}{l}\text { Universidad } \\
\text { Espíritu } \\
\text { Santo, } \\
\text { Ecuador. }\end{array}$ \\
\hline $\begin{array}{l}\text { 33. Measurement invariance in the } \\
\text { satisfaction with life scale in Chilean and } \\
\text { Ecuadorian older adults }\end{array}$ & Schnettler et al. (2017) & $\begin{array}{l}\text { Confirmation Factorial } \\
\text { Analysis. }\end{array}$ & $\begin{array}{l}\text { Chile \& } \\
\text { Ecuador }\end{array}$ & $\begin{array}{l}\text { Universidad } \\
\text { Católica de } \\
\text { Guayaquil, } \\
\text { Ecuador }\end{array}$ & $\begin{array}{l}\text { Universidad } \\
\text { de la } \\
\text { Frontera, } \\
\text { Chile. }\end{array}$ \\
\hline $\begin{array}{l}\text { 34. Focused, sustained and selective } \\
\text { attention systems in College Studenst, } \\
\text { Quito-Ecuador }\end{array}$ & $\begin{array}{l}\text { Ramos-Galarza, } \\
\text { Paredes, Andrade, } \\
\text { Santillán \& González } \\
(2016)\end{array}$ & $\begin{array}{l}\text { Comparison of } \\
\text { averages thru } \\
\text { ANOVA \& t-Student. }\end{array}$ & Ecuador & $\begin{array}{l}\text { Universidad } \\
\text { Internacional } \\
\text { SEK Ecuador }\end{array}$ & None \\
\hline
\end{tabular}

It is interesting to highlight that among the scientific production found in Ecuador, 2 papers were published between 1984 and 2000, and 6 between 2002 and 2012; this tendency changes starting in 2014 until 2017 where we find 26 published articles. This shift happened due to the changes in the University Accreditation System currently in place in Ecuador, which closed 14 universities in 2012 for not having any publications (not even in regional databases) nor counting with research professors with a PhD educational level (Long, 2013).

As consequence of this scenario, higher education institutions increased their scientific production, especially in the Faculty of Psychology which holds one of the most demanded majors by college students in Ecuador (Ramos et al. 2017). Nevertheless, in Ecuador, the number of published research is incipient if its defined percentage is based on the number of professors found in the local university system, who according to the current law should be writing scientific articles or books (Long, 2013).

According to our study, it is imperative to point out that other countries in Latin America have a greater scientific production compared to the 34 articles found in Ecuador in the area of psychology. For example, Chile reports 2768 articles, Colombia 2182, Peru 394 and Venezuela 363. This evidences the minuscule development if research in Ecuadorian psychology. Moreover, the mentioned neighbor countries don't just have articles that report research in psychology but most of them have their own journals for the publication of psychology papers, which are indexed in Web of Science or Scopus databases; this reflects their high scientific production in this field. 
One of the factors attributed to this scientific underdevelopment of psychology in Ecuador is the cultural belief that psychologists in this country don't need to master the processes of statistical calculations since their job is limited to providing psychotherapy from a professional standpoint and not to develop research studies. This scenario can be seen in the discourse of an important number of Ecuadorian psychology students who don't understand why they must take Statistic courses during their university studies (Ramos, 2017).

The described context of this paper has not been investigated in the country yet since, as far as we known, there is no prior research analyzing the causes of the low scientific production found in psychology in Ecuador. This is a matter of concern because the current regulation of University Accreditation considers scientific production as an indicator holding a high weight to determine the quality ranking of local universities (CEAASES, 2015).

In this context, the following research question arises: what is the perception of professionals and students of psychology regarding the causes of such low scientific production in Ecuador?, being the main object of the current research the identification of the perceptions associated to the use of statistics for scientific production in the field of Psychology in Ecuador.

\section{Method}

\section{Participants}

This research counted 410 participants, students and professionals of Psychology (73.0\% men and 26.8\% women) from different cities of Ecuador: Quito, Guayaquil, Latacunga, Durán, El Triunfo, Yaguachi, Lago Agrio, Esmeraldas, Ibarra, Chone, Pastaza, El Carmen, Cuenca, Ambato and Manta. The age range of the participants was 18 to 70 years old: $18-25$ years old $(71.9 \%), 26-30$ years old $(7.7 \%), 31-35$ years old $(7.4 \%), 36-40$ years old $(5.7 \%), 41-45$ years old $(3 \%), 46-50$ years old $(3 \%), 51-55$ years old $(0.5 \%), 56-60$ years old $(0.2 \%)$ and $61-70$ years old $(0.6 \%)$. As far as the education level of the subjects, $76.3 \%$ are college students following a psychology major, 14.2\% have an undergraduate degree in Psychology, $8.1 \%$ have a master in Psychology and $1.5 \%$ have a PhD in Psychology. In terms of their field of specialization $62.8 \%$ belonged to Clinical Psychology, 21.6\% Organizational Psychology, 10.5\% General Psychology, 2.9\% Education Psychology, 1.7\% Children Psychology and 0.5\% Legal Psychology.

\section{Research Design}

Research was carried out in two phases. In the first one, a quantitative study was performed on aspects related to statistics and scientific publications. In the second one, a qualitative study was done to deepen on the subjectivity immersed in learning and using statistics.

\section{Instruments}

For the quantitative phase an instrument was designed to evaluate the following variables: "like/dislike of statistics", "scientific publications", "usefulness perception", "importance of statistics" and "capacity to execute statistical analysis". Moreover, a scale of 14 items was 
applied where two complex variables were established: "negative believes related with statistics" and "anxiety responses when facing statistics". The first variable presented an indicator of adequate internal consistency $(\alpha=.85)$, the correlation between each of the items within the scale is between $.53-.70$ and it was not necessary to eliminate any item to improve the consistency coefficient internal. For the second variable, an appropriate reliability coefficient was also found $(\alpha=0.84)$, there was no need to eliminate any item in order to improve the alpha of internal consistency since the correlation between each item was between $.47-.70$.

For the qualitative study, open questions were made in order to deepen the understanding of the meaning constructions of students and professionals related to statistics in psychology, which allowed drawing a substantive theory.

\section{Data analysis techniques}

To explain the data, descriptive statistics with measures of central tendency and dispersion were applied. The Odds ratio technique was used to determine probabilities and to determine the association between variables correlation calculations were performed applying Student and Anova $t$ mean procedures.

In the qualitative stage, an open code linguistic analysis was performed and a coded paradigm based on the significances stated by the subjects was developed.

\section{Procedure}

Information gathering took place with the participation of fellow university professors in the field of psychology from different cities of Ecuador. The questionnaires were applied using Google survey forms, which permitted an immediate tabulation once filled by the subjects. Statistical analysis was made using the SPSS program version 23 and the qualitative analysis was done using ATLAS.ti. It is important to highlight that throughout the entire time of the study all the ethical parameters related to human research stated in Helsinki were followed: information confidentiality, protection of physical and psychological integrity of the people involved in the study, free willed participation or withdrawal from the study and complete information on the subjects of study (Williams, 2008).

\section{Results}

Results are organized according to both phases of the study: quantitative and qualitative. Such data is shown as follows:

\section{Phase 1: quantitative}

Relationship between liking/disliking statistics and the number of publications on indexed journals

To determine the link between liking or disliking statistics and other variables, three dichotomous questions were asked regarding the experience of the participants publishing 
scientific papers, where $3.40 \%$ have published an article at a regional level and $3.20 \%$ has been published in Scopus. As far as their preferences for statistics findings show that $53.30 \%$ gave a positive response while the other $46.70 \%$ dislike statistics. Table 2 show calculations obtained from the relationship between liking/disliking statistics and the number of published articles indexed in Latindex.

Table 2. Relation between taste for statistics and quantity of papers published in Latindex

\begin{tabular}{lcccc}
\hline & \multicolumn{2}{c}{ ¿Have you published any Latindex? } & & \\
\cline { 2 - 3 } & Yes & No & Pearson Chi-square & Fisher exact test \\
\hline Do you like Statistics? & & & & \\
\hline Yes & $3.7 \%$ & $96.3 \%$ & .76 & .79 \\
\hline No & $3.1 \%$ & $96.9 \%$ & & .79 \\
\hline
\end{tabular}

According to performed calculations, there is no significant relationship between the analyzed variables. Similar results can be seen in Table 3 which shows the link between liking/disliking statistics and the number of papers published in Scopus indexed journals.

Table 3. Relation between taste for statistics and quantity of Scopus Publications

\begin{tabular}{lcccc}
\hline & \multicolumn{2}{c}{ Have you published a } & & \\
\cline { 2 - 3 } & Scopus Article? & & \\
\cline { 2 - 3 } & Yes & No & Pearson Chi-square & Fisher exact test \\
\hline Do you like Statistics? & & & & \\
\hline Yes & $4.6 \%$ & $95.4 \%$ & .08 & .09 \\
\hline No & $1.6 \%$ & $98.4 \%$ & & .09 \\
\hline
\end{tabular}

Nevertheless, we can state that taking into account the dichotomous measures of statistics likings and the publication of articles indexed in Scopus or Latindex, participants that like statistics show a $1,18(95 \%$ IC, $.40-3.47)$ times higher probability to be published in a Latindex indexed journal compared to those who do not like statistics. Similarly, participants who like statistics have a $3.03(95 \%$ IC, $.82-11.16)$ times greater probability to have an article published in a Scopus index journal over those who don't.

At the same time, people who have already published a study in Latindex have a $17.02(95 \%$ IC, $4.48-64.66$ ) higher probability to publish a Scopus article opposed to those who have not been published with a regional indexation before.

\section{Relationship between professional instruction and number of publications in indexed journals}

To establish a link between education in statistics and the number of published articles, nonparametric calculations were performed. Table 4 shows the results. 
Table 4. Relation between education level and number of publications

\begin{tabular}{|c|c|c|c|c|c|}
\hline & A & B & $\mathrm{C}$ & $\mathrm{D}$ & $\mathrm{E}$ \\
\hline $\begin{array}{l}\text { A. How important do you consider taking Statistics is for the } \\
\text { education of professionals in psychology? }\end{array}$ & 1.00 & & & & \\
\hline B. What is your level of mastery of statistics processes? & -.05 & 1.00 & & & \\
\hline C. Number of Scopus published papers & -.05 & $.23^{* *}$ & 1.00 & & \\
\hline D. Number of Latindex published papers & .10 & .08 & $.29^{* *}$ & 1.00 & \\
\hline $\begin{array}{l}\text { E. How useful do you find statistics to be in the job of } \\
\text { psychologists? }\end{array}$ & -.06 & $.37^{* *}$ & .11 & .10 & 1.00 \\
\hline
\end{tabular}

Observation: $* *$ indicates $p<.01$

Table 4 shows a correlational analysis where the variable that represents the mastery of statistical processes is related with a statistical significance and direct proportionality with the quantity of published articles indexed in Scopus and Latindex, as well as with the one measuring the usefulness of statistics for a psychologist work.

\section{Relationship between psychological aspects and statistical knowledge}

To establish the relationship between elements related to statistical knowledge and aspects of psychology experience such as the believes regarding statistics and the anxiety that can be built when learning statistics, correlation calculations were performed as we can see on Table 5.

Table 5. Correlations between psychological aspects and perceptions of statistics knowledge

\begin{tabular}{lcc}
\hline & $\begin{array}{c}\text { Beliefs } \\
\text { regarding } \\
\text { Statistics }\end{array}$ & $\begin{array}{c}\text { Anxiety due to } \\
\text { Statistics }\end{array}$ \\
\hline $\begin{array}{l}\text { How important do you consider taking Statistics is for the education } \\
\text { of professionals in psychology? }\end{array}$ & .08 & .06 \\
What is your level of mastery of statistics processes? & $-.26^{* *}$ & $-.30^{* *}$ \\
Number of Scopus published papers & -.07 & -.03 \\
Number of Latindex published papers & -.09 & -.06 \\
How useful do you find statistics to be in the job of psychologists? & $-.18^{* *}$ & $-.39^{* *}$ \\
Beliefs regarding statistics & 1 & $.44^{* *}$ \\
Anxiety due to statistics & $.44^{* *}$ & 1 \\
\hline
\end{tabular}

As far as the relationship between the variables related to statistics negative perceptions and anxiety caused by statistics, results showed a link inversely proportional with the variable of 
mastery of statistical processes. Likewise, there is a link with the same characteristics between this variable and the one related to usefulness of statistics for psychologists.

Furthermore, other results were obtained according to sociodemographic variables. According to the ANOVA comparison procedure performed, no differences of statistical significance where found when comparing all the variables according to the age group of the participants. When comparing the variables based on the level of studies of the participants, results obtained showed that students enrolled in psychology majors are the ones who present greater negative believes regarding statistics $f_{(3,397)}=4.18, p=.006$ and higher levels of anxiety towards statistics $f_{(3,397)}=4.04, p=.008$. In terms of statistics usefulness, findings show that subjects with a PhD level of studies obtained a higher score in this variable $f_{(3,403)}=3.39, p=.01$ compared to the other levels of education.

A $t$ Student test was applied to compare all variables according to the subject's gender, the only statistical significant difference found was related to anxiety felt when dealing with statistics where women had a greater score $t_{(400)}=-1.97, p=.04$.

\section{Phase 2: Qualitative}

The following categories described below emerged from the participants' narratives regarding the presence of statistics in psychology:

\section{Erroneous believes regarding statistics}

A great percentage of participants mentioned disliking statistics when we asked to explain their answer, a perception on the value of statistics was identified. They argued against statistics procedures which unmasked their unawareness of the benefits statistical processes hold. Expressions such as "I don't feel statistics portrays human reality with numbers; it is not the only way to prove an hypothesis" (Psychology Student, 18 - 25 years old), "I don't think psychic occurrences can be reduce to numbers (...) human behaviors have multi-factors and are more complex so they can't be reduced to a number" (Masters in Psychology, 51 - 55 years old), "I don't like statistics, I'll rather base the results in social factors" (Psychology Student, 18 - 25 years old), "in my profession, it is not an vital axis when working with subjects (...) intervention is more important than classification" (Psychology PhD, 36 - 40 years old), "it is cold data used to justify studies (...) I am more oriented towards learning and understanding a human being as a whole and these numbers are not enough and end up forming generalizations" (Psychology Professional, 41 - 45years old), "statistics does not reflect changing reality" and "it can become a limit when working with human beings" (Master in Psychology, 36 - 40 years old).

\section{Statistics is based on the application of formulas}

Another expression related to have an aversion to statistics deals with the use of formulas to perform statistical calculations; participants expressed thins such as: "I don't like statistics because it has many formulas" (Psychology Students, 18 - 25 years old), "I am annoyed with statistics due to all the formulas" (Psychology Students, 18 - 25 years old), "handling formulas (c) Psy, Soc, \& Educ, 2019, Vol. 11(3) 
and statistics charts is pretty difficult at times" (Psychology Professional, 31 - 35 years old) and "statistics are useful but tedious because of the formulas" (Student of Psychology, 18 - 25 years old).

\section{Negative predisposition towards statistics}

Among the statements of the subjects who expressed their dislike towards statistics, we found that they have a set negative predisposition towards learning statistics, which has to do with participants believing they are incapable to perform calculations. The following statements were found among their responses: "statistics doesn't go with me because I am bad with numbers" (Psychology, 18 - 25 years old), "I hate working with numbers, it is too complicated" (Psychology Professional, 20 - 25 years old), "I hate numbers" (Psychology Student, 18 - 25 years old), "statistics does not attract me at all because it is a branch of mathematics" (Psychology Students, 18 - 25 years old), "I've never liked subjects that deal with numbers" (Psychology Student, 18 - 25 years old), "I don't like subjects related to mathematics" (Psychology Student, 18 - 25 years old). To sum up, a great percentage of students expressed having a negative mindset towards statistics, which comes from a prior belief of not being able to perform calculations. This builds a wall that affects the disposition of subjects to learn statistics for psychology.

\section{Statistics are hard and boring}

All participants were asked to summarize in one word the meaning of statistics. A common response was obtained majorly from women ( 19 women and 2 men), which stated that statistics are not an interested activity to waste their time during their professional education in Psychology since it is a subject with a high level of complexity and it becomes a difficult knowledge to acquire during college.

\section{Psychology is unrelated to Statistics}

Several participants are not clear on what statistics imply in psychology. They answered with expressions such as "I don't thing statistics are very necessary, they should teach us other subjects more aligned with our major" (Psychology Student, 18 - 25 years old), "I don't see the role of statistics in psychology" (Psychology Student, 18 - 25 years old), "I can't find the connection between statistics and psychology, it doesn't make sense" (Psychology Student, 18 - 25 years old), "statistics is useless, why do we need to learn it if we will become psychologists not economists" (Psychology Student, 18 - 25 years old), "I don't need to know statistics to practice psychology" (Psychology Professional, 46 - 50 years old) and "statistics is not as important for Clinical Psychology" (Psychology Student, 18 - 25 years old).

\section{Taste for Statistics}

Even if there was a significant negative predisposition towards statistics, there were statements found in favor of this subject among participants who are researchers and have published several articles indexed in Scopus. For them statistics have a positive connotation and its essential meaning is described as: a tool, an asset for the study, the research, to be precise and 
achieve perfection. This proves that researchers with experience have a positive predisposition towards using statistics as an essential element to carry out their research.

Moreover, among participants that have not published articles yet, there are some who expressed linking statistics. Some of their statements were: "I consider statistics necessary for the development of psychology as a science" (Psychology Student, 18 - 25 years old), "it is key to society" (Psychology Student, 18 - 25 years old), "it is a tool to strengthen an investigation" (Psychology Student, 18 - 25 years old), "it helps solve daily problems" (Psychology Student, 18 - 25 years old), "it helps validate studies with evidence" (Psychology Student, 18 - 25 years old), "it is a subject that handles logic calculations that are complex but once you get them they are extremely useful" (Psychology Student, 18 - 25 years old), "it is a very important tool in our profession because with it we can determine any survey or study we have performed" (Psychology Student, 18 - 25 years old), "it allows me to validate instruments" (Master in psychology, 31 - 35 years old) and "it lets me grasp the magnitude of social problems" (Psychology Professional, 26 - 30 years old).

\section{Coded Paradigm}

A coded paradigm was built based on the first word that comes to mind when the participants were asked to define statistics with one word (Figure 1).

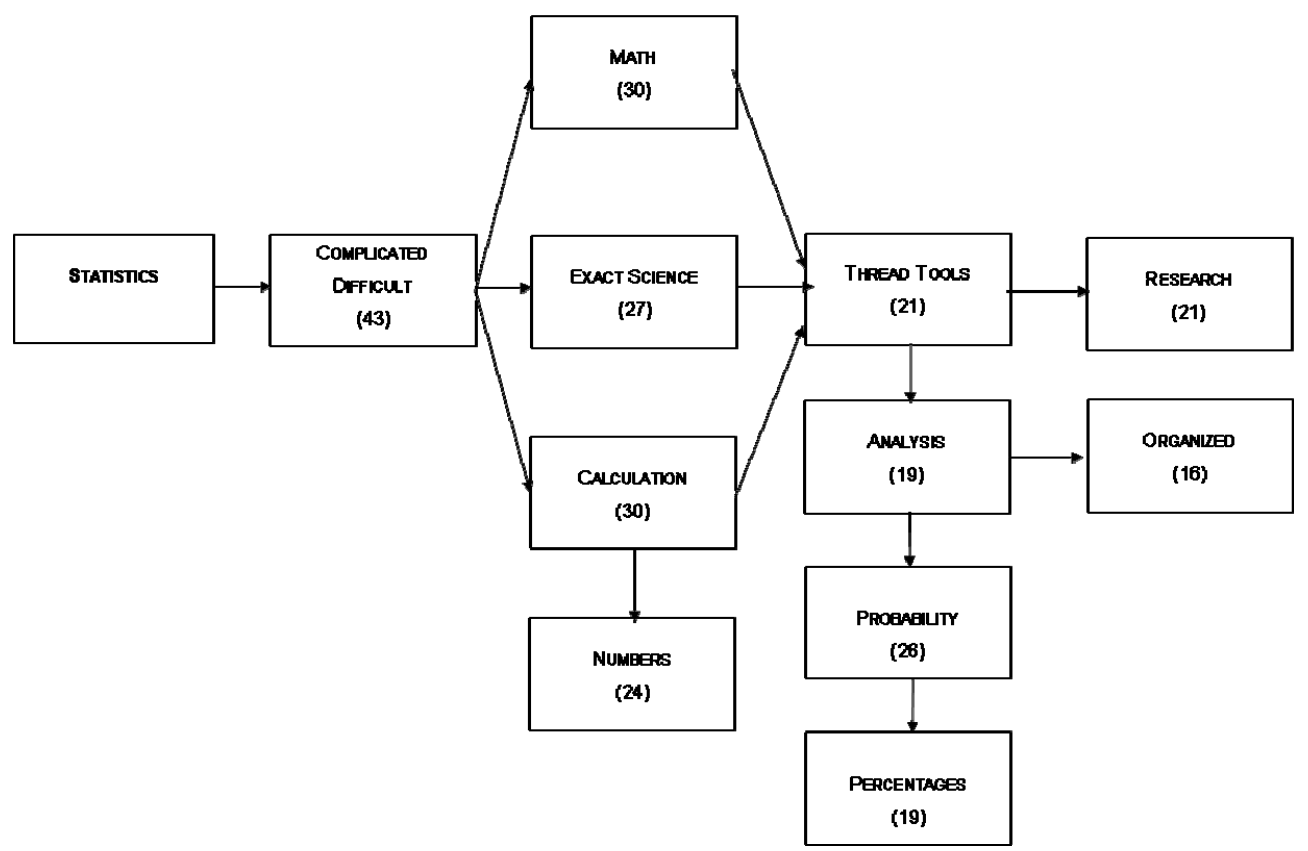

Figure 1. Coded Paradigm which interprets the meaning of statistics for the subjects of the study (frequency of the concept in parenthesis). According to the diagram constructed, the central category shows the role of statistics in psychology in Ecuador. It describes statistics as a complex/difficult activity from which exact mathematical calculations are drawn based on numbers that at the same time constitute a tool to perform an investigation. 


\section{Discussion}

The current standing of scientific production in Psychology in Ecuador is a great concern. Historically, it only includes 34 articles published for the country, which is alarming. A bibliometric study was recently reported on Psykhe Journal, one of the journals of greater prestige in Latin America for Psychology, where 531 articles published in this magazine were analyzed. The articles found were produced in Chile, Argentina, Peru, Venezuela, and Colombia among others of the region. Notwithstanding, there was not a single study from Ecuador published in this journal (Salas et al., 2016), which demonstrates how far behind is scientific research in psychology in the country.

In addition, from the Scopus Indexed publications reviewed in Ecuador, only 16 of the 34 published on behalf of Ecuadorian Institutions were carried out exclusively in Ecuador; 5 were collaboration between Ecuador and other countries; 13 were not written in Ecuador, researchers were abroad but had some kind of affiliation with an Ecuadorian University (Scopus, 2017). As far as the statistics analysis applied in those research papers, 6 articles carried out exclusively in Ecuador use frequencies and percentages as statistics tools (which is demonstrated with the coded paradigm of the qualitative phase where a high number of participants stated that statistics are just frequency and percentage calculations), while for the articles written in collaboration with other countries we find inferential statistics analysis of greater complexity. This scenario is concordant with our quantitative data findings where just a minimum number of participants have some kind of experience publishing research studies and in most cases, the use of statistics is limited to calculating basics such as percentages.

Regarding the role of statistics for the publication of articles, the response of participants showed that liking statistics and mastering their processes will increase the probability of developing a study that is accepted for publishing. Additionally, once one of these publications is indexed in a regional database, the chances of publishing a Scopus indexed study increases significantly as well (Ramos-Galarza, 2017a).

These findings should be considered by all Psychology majors in Ecuador since at the present time, students can obtain their degree by publishing a research study on Ecuadorian Psychology, which could be indexed regionally (CEAASES, 2015). This will build a culture of developing and publishing research papers of psychology and it will benefit psychology professors in Ecuador so they can publish their studies in Scopus indexed journals.

The qualitative data found in the first stage of the study was corroborated with the subjective constructions identified in the qualitative phase. Findings show that for subjects that have published one of their research studies see statistics as a useful tool to include in the scientific method. This is consistent with what was affirmed by Field (2009). On the contrary, the response of most participants that haven't published a paper was against the use of statistics or its value in Psychology. This situation is presented at the university level and in the postgraduate studies of psychology (Plans \& León, 2003). As we can see from the coded paradigm, the main meaning of statistics found was that statistics is a complicated and hard science from which mathematical analysis can be obtained that are basic to the investigation. 
The coded paradigm proposed in this study will allow us to understand why scientific production in Ecuador is so limited. In the context of psychology, we are dealing with the existence of subjective constructions that even if not stated clearly, influence the believes that psychology researchers have with respect to statistics. Even if statistics is a basic tool for the development of research studies, it is a complicated and difficult tool to use. This situation causes psychology students who have to study statistics to experience anxiety before this subject, which can negatively influence their learning (Khavenson, Orel, \& Tryakshina, 2012).

On the other side, the correlational quantitative analysis showed that when the negative preconceptions about statistics and level of anxiety related to its use increases then the mastery of statistical processes displayed by Psychology students and professionals diminishes (Onwuegbuzie \& Wilson, 2003). This result was not just evidenced at a quantitative level but it is also in agreement with the statements of the participants. At the qualitative levels we see that subjects with a lower ability level for statistics see this science as extremely complex and boring; furthermore they have their mind set negatively towards studying statistics even before they enroll or see what the class is about. They automatically dislike the subject without even starting its learning process.

Another erroneous belief drawn from the statements is the use of complex formulas as a basic element to learn statistics. This utterance cannot be further away from the true way of teaching statistics currently, where the value of learning is to master the essence of this subject which deals with understanding and applying with logic the procedures to prove the hypothesis thru diverse statistics methods. Nowadays, there are many statistical packages that handle all formulas automatically so statistics it is not about learning the formulas; it is about applying them correctly according to needs (Hernández, Fernández, \& Baptista, 2014).

The data retrieved from this research is not far from the reality lived in different contexts where psychology is studied. When a prospect student of psychology starts his major, he tends to regret his choice frequently when he finds out that the program of studies gives particular importance to statistics (Coolican, 1997). In Ecuador, most psychology major programs include two levels of statistics that need to be taken during the third and fourth semester of their undergraduate studies (Universidad Tecnológica Indoamérica, 2017).

One of the roots of the lack of interest in statistics discovered with this study is that in our country there is a low school performance in Mathematics. According to the Ministry of Education of Ecuador, the national mathematics evaluation results show that students of middle and high school have an insufficient level in this area of studies. Moreover, at an international level, Ecuador is one of the countries with lower development and performance in mathematics compared with others of the region (Fundación Ecuador y Grupo Faro, 2010). According to our data, this remains to be true at a university level as well. This will have a major impact on the professional formation of psychologists since a great percentage of students enroll in psychology programs to escape from mathematical analysis that need to be studied in order to pursue other majors or professions. 
Even if we have proven the importance of knowing and mastering statistics in order to publish a paper, it is also true that a psychology professional does not require this knowledge in order to have his research published as he can delegate to a member of the research team that dominates this process. This can be seen in our results among the non-significant correlations since findings show that in many cases to publish a paper, external experts where hired to perform statistical analysis, the member of the research team that handles these process is not a psychology scientist, or a study is published simply using a qualitative methodology or a theory background study.

Finally, we need to point out that as a constraint or limitation of the current study we have the subjective implication of the research team, which was submerged in the development of categories and the construction of the coded paradigm of the qualitative phase. This could have influenced our analysis, yet this potential bias was controlled with the participation and consensus of the research group to avoid leaving it to individual contributions or opinions.

The purpose beyond this study, and what is left to be done in the future, is to take the data presented in this paper and rebuild the education program offered to form psychology professionals in Ecuador. This science is as much as subjective as it is exact; we can apply methods containing a great linguistic richness as well as methods that need the highest statistical accuracy. We have a long way to walk, yet the end will justify all efforts. The challenge is to position Ecuadorian Psychology as a profession where students enroll in undergrad programs because they embrace the fact that it is a science that applies statistics methods and not because it is their last resort or they want to avoid working with numbers and calculations.

\section{Funding}

This work received no external funding.

\section{Ethical approval}

This research was approved by the ethics committee of the Indoamérica University of Ecuador. All procedures performed were in accordance with the 1964 Helsinki declaration and its later amendments or comparable ethical standards.

\section{Conflict of interest}

Authors declare no conflict of interest.

\section{References}

Álvarez, B., Aguirre, M., \& Vaca, S. (2010). Interacción Familia-Escuela. Análisis de contenido sobre el discurso de docentes y familias. REOP. 21 (2), 320-334.

Bojorque, G., Torbeyns, J., Hannula-Sormunen, M., \& Van Nijlen, L. (2016). Development of SFON in Ecuadorian Kindergartners. European Journal of Psychology of Education, 26, $1-14$. 
CEAASES [Consejo de Evaluación, Acereditación y Aseguramiento de la Calidad de la Educación Superior de Ecuador] (2015). Adaptación del Modelo de Evaluación Institucional de Universidades y Escuelas Politécnicas 2013 al proceso de Evaluación, Acreditación y Recategorización de Universidades y Escuelas Politécnicas 2015. QuitoEcuador: Retrieved on July 24 from: http://www.ceaaces.gob.ec/.

Coolican, H. (1997). Métodos de investigación y estadística en psicología. México D.F.: El Manual Moderno S.A.

Dekkers, L., Groot, N., Díaz, E., Andrade, I., \& Delfos, M. (2015). Prevalence of Autism Spectrum Disorders in Ecuador: A Pilot Study in Quito. Journal of Autism and Developmental Disorders, 12 (1), 4165-4173.

Field, A. (2009). Discovering Statistics Using SPSS. Third Edition. Los Angeles: SAGE.

Foster, T., Roth, M., Contreras, R., Gilmer, J., \& Gordon, J. (2012). Continuing bonds reported by bereaved individuals in Ecuador. Bereavement Care, 31 (3), 120-128.

Franco, E., Coterón, J., Martínez, H., \& Brito, J. (2017). Motivational profiles in physical education students from three countries and their relationship with physical activity. Suma Psicológica, 24 (1), 1-8.

González, D., Beltrán, P., \& Martínez, P. (2016). Exploring learning potential in schizophrenic inpatients in different psychopathological conditions. Clínica y Salud, 27 (2), 81-88. DOI: 10.1016/j.clysa.2016.04.003.

Gorenc, K., Bruner, C., Nadelsticher, A., Pacurucu, S., \& Feuerlein, W. (1984). A CrossCultural Study: A Comparison of German, Spanish and Ecuadorian Alcoholics Using the Munich Alcoholism Test (MALT). The American Journal of Drug and Alcohol Abuse, 10 (3), 429-446.

Hernández, R., Fernández, C., \& Baptista, P. (2014). Metodología de la Investigación. Sexta Edición. México D.F.: McGRAW-HILL / INTERAMERICANA EDITORES, S.A. DE C.V.

Haro, L., Ortega, C., De las Heras, M., Poyatos, A., Molina, M., Mar, M., . . . Olaverri, A. (2011). Evaluación de la astenia en pacientes oncológicos avanzados y una propuesta de protocolo de intervención psicológica. Psicooncología, 8 (1), 21-30.

Jiménez, J., Rodríguez, C., Suárez, N., O'Shanahan, I., Villadiego, Y., Uribe, C., . . Rodas, P. (2015). Teachers' implicit theories of learning to read: A cross-cultural study in IberoAmerican countries. Reading and Writing, 28 (9), 1355-1379.

Jurado, M., \& Rosselli, M. (2017). Automaticity of access to arithmetic knowledge in Alzheimer's disease and mild cognitive impairment. Psychology and Neuroscience, 10 (1), 57-76.

Khan, A. (2014). An investigation into prospective memory in children with developmental dyslexia. Frontiers, 5 (1308), doi: 10.3389/fpsyg.2014.01308.

Khavenson, T., Orel, E., \& Tryakshina, M. (2012). Adaptation of survey of attitudes towards statistics (SATS 36) for Russian sample. Procedia - Social and Behavioral Sciences, 46, 2126-2129. doi: 10.1016/j.sbspro.2012.05.440.

Lobos, G., Mora, M., Lapo, M., Caligari, C., \& Schnettler, B. (2015). Happiness and health and food-related variables: Evidence for different age groups in Chile. Suma Psicológica, 22 (2), 120-128. 
Long, G. (2013). "Suspendida por falta de calidad" El cierre de catorce universidades en Ecuador. En CEAACES, "Suspendida por falta de calidad" El cierre de catorce universidades en Ecuador (págs. 9-30). Quito, Ecuador: Consejo de Evaluación, Acreditación y Aseguramiento de la Calidad de la Educación Superior de Ecuador.

Mealy, M., Stephan, W., Mhaka-Mutepfa, M., \& Alvarado-Sánchez, L. (2015). Interpersonal Trust in Ecuador, the United States, and Zimbabwe. Cross-Cultural Research, 46 (4), 393-421.

Moyano, N., Byers, E., \& Sierra, J. (2016). Content and Valence of Sexual Cognitions and Their Relationship. Archives of Sexual Behavior, 45 (1), 2069-2080.

Moyano, N., Dib-Fayad, N., \& Vélez-Schemankewitz, M. (2017). Adaptation and validation of the sexual self-consciousness scale in Ecuadorian women. Sexual and Relationship Therapy, 32 (2), 155-172.

Moyano, N., P., V.-M., \& Sierra, J. (2017). Sexual Desire Inventory: Two or Three Dimensions? Journal of Sex Research, 54 (1), 105-116.

Onwuegbuzie, A., \& Wilson, V. (2003). Statistics Anxiety: Nature, etiology, antecedents, effect, and treatments--a comprehensive review of the literature. Teaching in Higher Education, 8 (2) , 195-209. doi.org/10.1080/1356251032000052447.

Pedrosa, I., García-Cueto, E., Torrado, J., \& Arce, C. (2017). Spanish adaption of passion scale in sport context. Revista Iberoanmericana de Diagnóstico y Evaluación Psicológica, 1 (43), 165-176.

Pérez-Salas, C., Ramos, C., Oliva, K., \& Ortega, A. (2016). Bifactor modeling of the behavior rating inventory of executive function (BRIEF) in a Chilean sample. Perceptual and Motor Skills, 122 (3), 757-776.

Plans, B., \& León, O. (2003). ¿Cómo debe ser el Doctorando ideal en Psicología? Contesta el Oráculo de Delfos. Psicothema, 15 (4), 610-614.

Pluck, G., Brooker, C., Blizard, R., \& Moran, P. (2015). Personality disorder in a probation cohort: Demographic, substance misuse and forensic characteristics. Criminal Behavior and Mental Health, 25 (5) , 403-415.

Power, Y., Power, L., \& Canadas, M. (2008). Low socioeconomic status predicts abnormal eating attitudes in Latin American female adolescents. Eating Disorders, 16, 136-145. Fundación Ecuador y Grupo Faro. (2010). ¿Cambio educativo o educación por el cambio? Informe de Progreso Educativo Ecuador 2010. Quito-Ecuador.

Proctor, B., Kranzler, J., Rosenbloom, A., Martínez, V., \& Guevara-Aguire, J. (2000). An initial investigation of validation of the matrix analogies test-expanded form in Ecuador. Psychological Reports, 86, 445-453.

Ramos, C. (2017a). Introducción a la investigación: entre anécdotas musicales y científicas. Quito, Ecuador: Editorial Don Bosco.

Ramos-Galarza, C. (2017b). El abandono de la Estadística en la Psicología de Ecuador. Revista chilena de neuro-psiquiatría, 55 (2), 110-113.

Ramos, C., Barrios, A., Paredes, L., Santillán, W., Andrade, S., \& González, L. (2017). Ingreso de estudiantes al sistema educativo superior: estudio de caso de la carrera de Psicología de la universidad Internacional SEK del Ecuador. Avances en Psicología, 25 (1), 73-84. 
Ramos-Galarza, C., Paredes, L., Andrade, S., Santillán, W., \& González, L. (2016). Focused, sustained and selectiveattention systems in College Students, Quito-Ecuador [Sistemas de Atención Focalizada, Sostenida y Selectiva en Universitarios de Quito-Ecuador. Revista Ecuatoriana de Neurología, 25 (1-3), 34-38.

Ramos, V., Mejía, S., Mejía, K., Unada, X., \& Jordão, F. (2017). Validation for the ecuadorian context of the APO inventory created in Portugal. Revista Iberoamericana de Diagnóstico y Evaluación Psicológica, 1 (43), 123-133. DOI: 10.21865/RIDEP43_123.

Ramos-Galarza, C. \& Pérez-Salas, C. (2017). Control inhibitorio y monitorización en población infantil con TDAH. Avances en Psicología Latinoamericana, 35(1), 117-130. doi: http://dx.doi.org/10.12804/revistas.urosario. edu.co/apl/a.4195

Rodríguez-Mancilla, M., \& Boada, M. (2016). Investigación-acción-participativa y renovación urbana en el barrio patrimonial La Ronda de Quito. Revista Interamericana de Psicología, 50 (1), 86-95.

Romo, M., Abril-Ulloa, V., \& Kelvin, E. (2016). The relationship between hunger and mental health outcomes among school-going Ecuadorian adolescents. Social Psychiatry and Psychiatric Epidemiology, 51 (6), 827-837.

Salas, G., Ponce, F., Méndez-Bustos, P., Vega-Arce, M., Pérez, M., López-López, W., \& Cárcamo-Vásquez, H. (2017). 25 años de Psykhe: Un análisis bibliométrico. PSYKHE, 26 (1), 1-17.

Schnettler, B., Miranda-Zapata, E., Lobos, G., Lapo, M., Adasme-Berrío, C., \& Hueche, C. (2017). Measurement invariance in the satisfaction with life scale in Chilean and Ecuadorian older adults. Personality and Individual Differences, 110 (1), 96-101.

Scopus. (2017). Investigaciones publicadas en Ecuador en Psicología. Recuperado el 15 de julio de 2017 de: https://www.scopus.com/search/form.uri?display=basic.

Soriano-Ferrer, M., \& Piedra-Martínez, E. (2016). Un análisis documental de la investigación en dislexia en la edad adulta. Universitas Psychologica, 193-203.

Trueba, A., Simon, E., Auchus, R., \& Ritz, T. (2016). Cortisol response to acute stress in asthma: Moderation by depressive mood. Psysiology and Behavior, 159, 20-26.

Universidad Tecnológica Indoamérica de Ecuador. (2017). Malla Curricular de la carrera de Psicología. Recuperado el 31 de mayo de 2017 de: http://www.uti.edu.ec/documents/Malla_Curricular_Psicologia.pdf.

Williams, J. (2008). Revising the declaration of Helsinki. World medical journal. 54 (4), 120 122.

Xu, S., Martínez, L., VanHoof, H., Eljuri, M., \& Arciniegas, L. (2016). Fluctuating emotions: relating emotional variability and job satisfaction. Journal of Applied Social Psychology, 46 (11), 617-626.

Zemp, A. (2002). Sexualised violence against people with developmental disabilities in institutions. Praxis der Kinderpsychologie und Kinderpsychiatrie, 51 (8), 610-625. 